\title{
PENGGUNAAN MEDIA KARTU KATA BERGAMBAR UNTUK MENINGKATKAN PENGUASAAN KOSAKATA BAHASA SUNDA ANAK USIA DINI PADA KELOMPOK B DI TK PGRI CIBEUREUM
}

\author{
Yasbiati $^{1}$, Oyon Haki Pranata ${ }^{2}$, Fitriani Fauziyah ${ }^{3}$ \\ ${ }^{1}$ Program Studi PGPAUD UPI Kampus Tasikmalaya \\ ${ }^{2}$ Program Studi PGSD UPI Kampus Tasikmalaya \\ ${ }^{3}$ Program Studi PGPAUD UPI Kampus Tasikmalaya
}

Email: yasbiati@upi.edu

(Received: Mei 2017; Accepted: Mei 2017; Published: Juni 2017)

\begin{abstract}
This study was conducted based on findings related problem with the lack of vocabulary Sundanese early childhood on the group B TK PGRI Cibeureum, this is due to lack of familiarity and use of Sundanese language, as well as the stimulus provided only a librettist. One alternative used in this research is using pictorial word card media. According to some media experts said display card can enhance or enrich the vocabulary of early childhood. This study aims to improve the mastery of vocabulary early childhood Sundanese language using pictorial word card mediain group B at TK PGRI Cibeureum. This study uses a Class Action Research (PTK) and implemented in the B2 group TK PGRI Cibeureum Cibeureum District of Tasikmalaya in the second semester of the academic year in 2017 with the number of students amounted to 10 people. In addition to children, the subjects in this study were researchers, partners and media researcher pictorial word card. Classroom Action Research (CAR), which held 3 cycle by using models Kemmis and Taggart and using data collection techniques of observation and documentation. Results of research conducted showed an increase, this is evidenced by an increase in the ability of teachers in planning lessons, the ability of the teacher in the learning process, the ability of teachers in the use of media and word cards pictorial vocabulary Sundanese early childhood. Recommendations for teachers is illustrated word cards can be used as a medium of learning that children do not feel bored in learning.
\end{abstract}

Keywords: early childhood, Sundanese language vocabulary, illustrated word cards

\begin{abstract}
ABSTRAK
Penelitian ini dilakukan berdasarkan temuan masalah yang berkaitan dengan masih kurangnya kosakata bahasa Sunda anak usia dini pada kelompok B di TK PGRI Cibeureum, hal ini dikarenakan kurangnya pembiasaan dan penggunaan bahasa Sunda, serta stimulus yang diberikan hanya berupa nyanyian. Salah satu alternatif yang digunakan dalam penelitian ini yaitu menggunakan media kartu kata bergambar. Menurut beberapa ahli media kartu kata bergambar dapat meningkatkan atau memperkaya kosakata anak usia dini. Penelitian ini bertujuan untuk meningkatkan penguasaan kosakata bahasa sunda anak usia dini menggunakan media kartu kata bergambarpada kelompok B di TK PGRI Cibeureum. Penelitian ini menggunakan Penelitian Tindakan Kelas (PTK) dan dilaksanakan di kelompok B2 TK PGRI Cibeureum Kecamatan Cibeureum Kota Tasikmalaya pada semester genap tahun ajaran 2017 dengan jumlah peserta didik berjumlah 10 orang. Selain anak, subjek dalam penelitian ini adalah peneliti, mitra peneliti dan media kartu kata bergambar. Penelitian Tindakan Kelas (PTK) yang dilaksanakan sebanyak 3 siklus dengan menggunakan model kemmis dan taggart serta menggunakan teknik pengumpulan data observasi dan dokumentasi. Hasil penelitian yang telah dilaksanakan menunjukkan peningkatan, hal ini dibuktikan dengan adanya peningkatan kemampuan guru dalam merencanakan pembelajaran, kemampuan guru dalam proses pembelajaran, kemampuan guru dalam penggunaan media kartu kata bergambar serta penguasaan kosakata bahasa Sunda anak usia dini. Rekomendasi untuk guru yaitu kartu kata bergambar dapat digunakan sebagai salah satu media dalam pembelajaran agar anak tidak merasa jenuh dalam pembelajaran.
\end{abstract}

Kata kunci : anak usia dini, kosakata bahasa Sunda, kartu kata bergambar 


\section{Pendahuluan}

Pendidikan anak usia dini (PAUD) merupakan pendidikan yang sangat penting bagi anak usia dini, karena pada masa ini terdapat masa keemasan golden age. Pada masa ini perkembangan anak sangat pesat dan terjadi sekali seumur hidup. Apabila masa ini diabaikan atau tidak diberi stimulus maka akan berdampak bagi kehidupan anak dimasa datang, sehingga stimulus harus diberikan secara optimal. Menurut Mansur (2005, hlm.8) pendidikan anak usia dini merupakan salah satu bentuk penyelenggaraan pendidikan yang menitikberatkan pada peletakan dasar ke arah pertumbuhan dan enam perkembangan yaitu : perkembangan moral dan agama, perkembangan fisik, kecerdasan/kognitif, sosio-emosional, bahasa dan komunikasi, sesuai dengan keunikan dan tahap-tahap perkembangan sesuai kelompok usia yang dilalui oleh anak usia dini.

Bahasa merupakan hal sangat penting bagi kehidupan, karena tanpa bahasa kita tidak dapat berkomunikasi dengan orang lain. Perkembangan bahasa merupakan salah satu aspek yang dapat dikembangkan di PAUD, dengan demikian kemampuan berbahasa harus diasah dan dikembangkan sejak anak usia dini. Aspek yang berkaitan dengan perkembangan bahasa lisan anak salah satunya adalah kosakata. Menurut Tarigan (2011, hlm. 72) kosakata merupakan himpunan kata yang diketahui oleh seseorang atau merupakan bagian dari suatu bahasa tertentu, yang kemungkinan akan digunakan oleh seseorang untuk menyusun kalimat baru. Bahasa merupakan salah satu ciri khas suatu suku, ras atau bangsa. Ciri khas suku Sunda yaitu bahasa Sunda. Bahasa sunda merupakan bagian dari budaya sunda. Seiring berkembangnya zaman, penggunaan bahasa sunda sudah mulai terkikis. Orang sunda lebih banyak menggunakan bahasa Indonesia daripada menggunakan bahasa sunda, orang menganggap bahwa bahasa sunda merupakan bahasa yang rumit dengan segala undak usuk basa nya. Sehingga orang tua membiasakan kepada anak mereka untuk berbahasa indonesia. Menurut Santrock dalam Dhienie (2008, hlm. 1.17) meskipun kebudayaan manusia memiliki berbagai variasi dalam bahasa namun terdapat beberapa karakteristik umum berkenaan dengan fungsi bahasa sebagai alat untuk berkomunikasi dan adanya daya cipta individu yang kreatif.

Melihat kondisi lapangan di TK PGRI Cibeureum usia 5-6 tahun, banyak anak yang kurang memahami bahasa sunda. Kosakata anak masih minim, tingkat kefasihan anak berbicara bahasa sunda masih kurang dan pembedaan penyebutan huruf vokal eu, e, dan è. Pada saat istirahat, peneliti menanyakan kepada anak warna apa ini ? (sambil menunjuk perosotan berwarna biru menggunakan bahasa sunda), anak menggelengkan kepala dan menjawab tidak tahu. Oleh karena itu anak usia dini perlu pembiasaan dan bimbingan dari orang dewasa. Kondisi ideal untuk penguasaan kosa kata anak usia dini pada usia 5-6 tahun adalah mengerti kosakata dasar. Kosakata dasar ini akan memberikan pengetahuan untuk bekal anak nanti. Sehingga anak akan dapat berkomunikasi dengan orang tua, masyarakat, teman-temannya menggunakan bahasa sunda. Kemudian masalah lain yaitu guru hanya mengenalkan bahasa sunda pada saat anak berbaris, yaitu melalui nyanyian, sedangkan pada pembelajaran menggunakan bahasa Indonesia.

\section{Tinjauan Pustaka}

Menurut Badudu (dalam Dhieni, 2007, hlm. 1.10) 'bahasa adalah alat penghubung atau komunikasi antara anggota masyarakat yang terdiri dari individu-individu yang menyatakan pikiran, perasaan dan keinginannya'.

Menurut Stice, Bertrand \& Bertrand (dalam Otto, 2015, hlm.3) 'bahasa membentuk dasar persepsi, komunikasi, dan interaksi harian kita. Bahasa merupakan 
suatu sistem simbol yang mengkategorikan, mengorganisasi, dan mengklarifikasi pikiran kita'.

Dari beberapa pendapat para ahli diatas dapat disimpulkan bahwa bahasa alat komunikasi antar masyarakat untuk menyampaikan pikiran, perasaan dan keinginannya berupa simbol baik berupa lisan maupun tulisan.

Tugas-tugas perkembangan bahasa yang diharapkan dicapai pada lingkup perkembangan bahasa rentang usia 4-6 tahun sesuai dengan Permendikbud Nomor 137 Tahun 2014 terbagi menjadi 3 bagian utama yaitu memahami bahasa, mengungkapkan bahasa, dan keaksaraan. Tingkat pencapaian perkembangan anak usia 5-6 tahun dalam lingkup perkembangan bahasa akan diuraikan sebagai berikut.

1) Menerima Bahasa

a) Mengerti beberapa perintah secara bersamaan

b) Mengulang kalimat yang lebih kompleks

c) Memahami aturan dalam suatu permainan

d) Senang dan menghargai bacaan

2) Mengungkapkan Bahasa

a) Menjawab pertanyaan yang lebih kompleks

b) Menyebutkan kelompok gambar yang memiliki bunyi yang sama

c) Berkomunikasi secara lisan, memiliki perbendaharaan kata, serta mengenal simbol simbol untuk persiapan membaca, menulis dan berhitung

d) Menyusun kalimat sederhana dalam struktur lengkap (pokok kalimat-predikatketerangan)

e) Memiliki lebih banyak kata-kata untuk mengekspresikan ide pada orang lain

f) Melanjutkan sebagian cerita/dongeng yang telah diperdengarkan

g) Menunjukkan pemahaman konsepkonsep dalam buku cerita

3) Keaksaraan

a) Menyebutkan simbol-simbol huruf yang dikenal b) Mengenal suara huruf awal dari namanama benda yang ada disekitarnya

c) Menyebutkan kelompok gambar yang memiliki bunyi/huruf awal yang sama

d) Memahami hubungan antara bunyi dan bentuk huruf yang sama

e) Membaca nama sendiri

f) Menuliskan nama sendiri

g) Memahami arti kata dalam cerita

Penguasaan kosakata termasuk kedalam mengungkapkan bahasa yaitu memperkaya dan mengucapkan kosakata sehari-hari yang berkaitan dengan lingkungan sekitar.

Dalam Keputusan Gubernur Jawa BaratNomor: 423.5/Kep.674Disdik/2006TentangStandar Kompetensi dan Kompetensi Dasar serta Panduan Penyusunan Kurikulum Tingkat Satuan Pendidikan Mata Pelajaran Bahasa dan Sastra Sunda, disebutkan fungsi dan tujuan pengembangan bahasa Sunda di Taman Kanak-kanak atau Raudhatul Atfal. Adapun fungsi dan tujuan tersebut antara lain :

1) Fungsi

Pengembangan kemampuan berbahasa Sunda bagi anak TK/RA berfungsi sebagai berikut, yakni:

a) alat untuk berkomunikasi dengan lingkungan;

b) alat untuk mengembangkan intelektual anak;

c) alat untuk mengembangkan ekspresi anak; dan

d) alat untuk menyatakan perasaan dan buah pikiran kepada orang lain.

2) Tujuan

Pengembangan kemampuan berbahasa Sunda di TK/RA bertujuan agar:

a) Anak didik memperoleh pengalaman berbahasa Sunda;

b) Anak didik mampu berkomunikasi dengan menggunakan bahasa Sunda.

c) Anak didik menghargai dan membanggakan bahasa Sunda sebagai bahasa ibu, bahasa daerah, dan bahasa resmi kedua di Jawa Barat setelah bahasa Indonesia 
Mengembangkan kosakata merupakan tugas kedua dari perkembangan berbicara, kosakata akan meningkat sejalan dengan bertambahnya usia. Menurut Hurlock (1978, hlm. 185-187) Tugas pertama berbicara adalah :

Belajar pengucapan, kemudian tugas kedua dalam belajar berbicara adalah mengembangkan jumlah kosakata. Anak mempelajari dua jenis kosakata yakni kosakata umum dan kosakata ganda khusus. Peningkatan jumlah kosakata tidak hanya karena mempelajari katakata baru, tetapi juga mempelajari arti baru pada kata-kata lama. Sedangkan tugas ketiga dalam berbicara adalah pembentukan kalimat. Pada setiap tingkatan umur, anak memperlihatkan perbedaan individual yang menonjol dalam pembentukkan kalimat baik mengenai panjang maupun polanya. Pada waktu anak berusia tahun, kalimat mereka hampir lengkap, dan setahun kemudian kalimatnya sudah lengkap berisi semua unsur kalimat.

Acquiring vocabulary is very important part of the process of learning a language. Teachers can help children develop vocabulary by reading to them and by engaging them in such activities as listening and word games,discussions, dramatizations, and role playing, and storrytelling with puppets.(Winsor,2009, hlm.11).

Artinya pemerolehan kosakata adalah bagian yang sangat penting dari proses proses pembelajaran bahasa. Guru dapat membantu anak untuk mengembangkan kosakata dengan membaca dan mengajak mereka dalam beberapa kegiatan diantaranya mendengarkan dan bermain kata, diskusi, dramatisasi dan bermain peran, dan bercerita menggunakan boneka.

"Penguasaan kosakata pada masa kanakkanak berawal dari kosakata umum kemudian kosakata khusus." (Hurlock, 1987, hlm.185187). Untuk menguasai kosakata, anak harus mampu melafalkan kata dan menyebutkan makna dari kata tersebut. sehingga dapat menyusun kalimat yang sederhana. Menurut Tarigan (2011, hlm.2) "kualitas keterampilan berbahasa seseorang bergantung kepada kualitas dan kuantitas kosakata yang dimilikinya. Semakin kaya kosakata yang kita miliki, semakin besar pula kemungkinan kita terampil berbahasa".

Adapun kosakata bahasa Sunda yang digunakan pada pembelajaran di Taman Kanak-kanak diseuaikan dengan tema pembelajaran yang sedang dilaksanakan, yaitu:

a. Panon poé artinya matahari

b. Béntang artinya bintang

c. Katumbiri artinya pelangi

d. Béntar artinya petir

e. Kayas artinya merah muda

f. Bulao artinya biru

g. Bungur artinya ungu

h. Kulawu artinya abu-abu

Pada dasarnya kegiatan anak tidak terlepas dari aktivitas bermain. Dockett dan Fleker dalam Nurani (2013, hlm. 144) berpendapat bahwa bermain merupakan kebutuhan bagi anak, karena melalui bermain anak akan memperoleh pengetahuan yang dapat mengembangkan kemampuan dirinya. Menurut Mukhtar (2013, hlm. 152) Jika dikaitkan dengan pendidikan anak usia dini, media pembelajaran brarti segala sesuatu yang dapat dijadikan bahan dan alat untuk bermain yang membuat anak usia dini memperoleh pengetahuan, keterampilan dan menentukan sikap.

Salah satu media yang dapat menarik perhatian anak dan meningkatkan penguasaan kosakata bahasa sunda anak usia dini yaitu kartu kata bergambar. Menurut Gelfgren (2012, hlm. 1) Anak belajar dengan cara yang berbeda, dan mayoritas menggunakan cara-cara visual. Kartu kata bergambar dapat digunakan untuk subjek apapun, misalnya melatih pembelajaran bahasa dasar (kosakata dan tata bahasa), matematika, biologi, dan geografi. Kartu kata bergambar mudah digunakan, sangat berguna untuk guru, dan dapat digunakan disetiap 
tingkatan kelas. Menurut Arsyad (1997, hlm.119-121) kartu kata bergambar (flashcard) adalah kartu kecil yang berisi gambar, teks, atau tanda simbol yang mengingatkan atau menuntun siswa kepada sesuatu yang berhubungan dengan gambar itu. Flashcard biasanya berukuran $8 \times 12 \mathrm{~cm}$, atau dapat disesuaikan dengan besar kecilnya kelas yang dihadapi. Kartu abjad dapat digunakan untuk latihan mengeja lancar. Kartu yang berisi gambar-gambar dapat digunakan untuk melatih siswa mengeja dan memperkaya kosakata. Kartu-kartu tersebut menjadi petunjuk dan rangsangan bagi siswa untuk memberikan respons yang diinginkan.

Media kartu kata bergambar merupakan media visual yang tidak diproyeksikan. Setiap media pembelajaran memiliki kelebihan dan kelemahan.

Adapun kelebihan media kartu kata bergambar menurut Susilana dan Cepi (2009, hlm 95) diantaranya :

1) Mudah dibawa

Dengan ukuran yang kecil, media kartu kata bergambar dapat disimpan di tas bahkan di saku, sehingga tidak membutuhkan ruang yang luas, dan dapat digunakan di dalam atau di luar kelas.

2) Praktis

\section{Metode Penelitian}

Desain penelitian yang digunakan adalah Penelitian Tindakan Kelas (PTK). Menurut Wardhani dan Kuswaya (2009, hlm.1.3) Penelitian Tindakan Kelas merupakan terjemahan dari Classroom Action Research, yaitu Action Research yang dilakukan di kelas. Sedangkan menurut Arikunto (2013, hlm. 130) penelitian tindakan kelas (PTK) merupakan suatu pencermatan terhadap kegiatan yang sengaja dimunculkan, dan terjadi dalam sebuah kelas. Menurut Suhardjono dalam Dimyati (2014, hlm. 119) pengertian tindakan kelas yaitu penelitian yang dilaksanakan oleh guru, bekerja sama dengan peneliti atau dilakukan oleh guru sendiri yang juga bertindak sebagai
Dilihat dari cara pembuatan dan penggunaannya, media kartu kata bergambar sangat praktis, tidak menggunakan listrik

3) Mudah Diingat

Karateristik media kartu kata bergambar adalah menyajikan pesan-pesan pendek pada setiap kartu disajikan. Sajian pendek ini akan memudahkan siswa untuk mengingat pesanpesan tersebut. Kombinasi antara gambar dan teks cukup memudahkan siswa untuk mengenali suatu konsep.

4) Menyenangkan

Media kartu kata bergambar dalam penggunaannya bisa melalui permainan.

Sedangkan kelemahan media kartu kata bergambar yaitu anak hanya dapat mengetahui dan memahami kata dan gambar yang ada pada media kartu kata bergambar, dengan kata lain pengetahuan anak terbatas pada kartu kata bergambar yang disajikan.

Bagi kebanyakan anak, penggunaan kartu kata bergambar adalah cara yang menyenangkan untuk belajar kosakata baru dan tata bahasa. Berdasarkan permasalahan tersebut peneliti melaksanakan Penelitian Tindakan Kelas (PTK) dengan judul penelitian "Penggunaan Media Kartu Kata Bergambaruntuk Meningkatkan Penguasaan Kosakata Bahasa Sunda Anak Usia Dini pada Kelompok B di TK PGRI Cibeureum". peneliti di kelas atau di sekolah tempat kerjanya, dengan penekanan pada penyempurnaan atau peningkatan proses dan hasil pembelajaran. Metode penelitian yang digunakan dalam penelitian ini adalah metode yang di ambil dari Kemmis dan Mc. Taggart dalam Arikunto (2013, hlm.138-140) mengembangkan bahwa satu putaran dalam sebuah siklus terdiri dari empat tahap. Tindakan yang diterapkan meliputi tahapan sebagai berikut : Tahap 1 : menyusun rancangan tindakan (perencanaan); Tahap 2 : pelaksanaan tindakan; Tahap 3 : pengamatan; Tahap 4 : refleksi atau pantulan. Subjek dalam penelitian ini yaitu anak usia dini kelompok B2 TK PGRI Cibeureum berjumlah 10 anak, yang terdiri dari 5 anak 
laki-laki dan 5 anak perempuan. Selain anak, subjek dalam penelitian ini adalah guru dan kepala sekolah TK PGRI Cibeureum. Instrumen yang digunakan dalam penelitian ini yaitu lembar observasi dan dokumentasi. Lembar observasi yang digunakan yaitu lembar observasi kemampuan guru dalam merencanakan pembelajaran, kemampuan guru dalam proses pembelajaran, lembar observasi kemampuan guru dalam penggunaan media kartu kata bergambar, dan lembar observasi penguasaan kosakata bahasa Sunda anak usia dini. Sebelum ke lapangan mengambil data, instrumen yang telah di buat di validsi terlebih dahulu oleh para ahli. Dalam Apriliani (2016, hlm.42) teknik analisis data pada penelitian tindakan kelas adalah :

1. Teknik Codingdan labelling, adalah penetapan atau pengelompokkan jenis kinerja yang diobservasi dan direfleksi pada setipa siklus tindakan.

2. Teknik Triangulasi, teknik pengolahan data yang bersifat menggabungkan dari berbagai sumber yang telah ada.

3. Teknik Saturasi (kejenuhan), teknik ini digunakan dengan alasan keterbatasan waktu yang dimiliki peneliti. Teknik ini memastikan bahwa tindakan dan hasil perbaikan ditetapkan dengan batas optimal keberhasilan.

4. Common Sense, adalah cara mengetahui berdasarkan pengalaman sehari-hari. Teknik ini dilakukan dengan cara meminta komentar kepada orang lain yang lebih dianggap paham dan lebih mengerti tentang permasalahan yang akan dihadapi dalam penelitian.

\section{Hasil dan Pembahasan}

Penelitian tindakan kelas yang telah dilakukan peneliti terdiri dari tiga siklus. Pelaksanaan siklus I berlangsung pada tanggal 27 April 2017 tema benda langit sub tema Matahari (Panon Poé), pelaksanaan siklus II pada tanggal 29 April 2017 tema gejala alam sub tema Pelangi (Katumbiri) dan pelaksanaan siklus III pada tanggal 2 Mei 2017 tema gejala alam sub tema Petir (Béntar). Penelitian ini menggunakan media kartu kata bergambar untuk meningkatkan penguasaan kosakata bahasa Sunda anak usia dini kelompok B di TK PGRI Cibeureum.

1. Kemampuan Guru dalam Merencanakan Pembelajaran

Kemampuan guru dalam merencanakan pembelajaran pada Penelitian Tindakan Kelas (PTK) ini dituangkan dalam tiga buah Rencana Pelaksanaan Pembelajaran Harian (RPPH). Pada tiga siklus tindakan, peningkatan kemampuan guru dalam merencanakan pembelajaran adalah : pada siklus I jumlah skor yang diperoleh guru dalam membuat merencanakan pembelajaran adalah 11,55 dengan persentase 72,18\% (belum mencapai indikator keberhasilan yang telah ditentukan). Kelemahan pada perencanaan pembelajaram siklus I adalah pengembangan tema/sub tema dan penentuan metode yang dipilih kurang tepat sehingga berpengaruh terhadap proses pembelajaran. Pada siklus II kekurangan pada perencanaan pembelajaran tersebut dapat diatasi oleh guru sehingga mengalami peningkatan sebesar 0,78 dengan persentase 4,88\% menjadi 12,33 dengan persentase $77,06 \%$. Kelemahan pada siklus II yaitu menentukan dan merencanakan format penilaian proses pembelajaran. Pada siklus III kekurangan tersebut dapat diatasi oleh guru sehingga mengalami peningkatan sebesar 1,53 dengan persentase 9,56\%, menjadi 13,86 dengan persentase $86,62 \%$. Nampak bahwa peningkatan kinerja dengan gain (rentang) tertinggi adalah siklus II ke siklus III mengalami peningkatan sebesar 1,53 dengan persentase $9,56 \%$. Hal ini terjadi karena pada siklus III upaya guru dalam memperbaiki Rencana Pelaksanaan Pembelajaran Harian dilakukan dengan optimal.

2. Kemampuan Guru dalam Proses Pembelajaran

Kemampuan guru dalam proses pembelajaran dengan menggunakan media 
kartu kata bergambar dapat meningkatkan aktivitas siswa dalam pembelajaran, dimana guru bertindak sebagai fasilitator dan motivator. Kemampuan peneliti dalam melaksakan kegiatan pembelajaran pada siklus I mencapai 7,55 dengan persentase $62,91 \%$. Ada beberapa aspek yang harus diperbaiki yaitu : a. Pada saat pembahasan tema, usahakan dari tema ke sub tema; b. Penyampaian materi masih kaku dan perhatikan pengelolaan kelas, usahakan semua anak ikut aktif dalam kegiatan, sehingga tidak ada anak yang asyik main sendiri; c. Media gambar besar didepan kelas tetap harus dibuat, untuk pembahasan tema dan untuk pemusatan fokus anak; d. Pada penggunaan media kartu kata bergambar, guru kurang memberikan keleluasaan kepada anak; d. Guru kurang memberikan penguatan kepada anak. Pada siklus II kelemahankelemahan peneliti dalam pelaksanaan diperbaiki, kemampuan melaksanakan kegiatan mengalami peningkatan sebesar 1,065 dengan persentase $8,89 \%$, menjadi 8,615 dengan persentase $71,80 \%$. Pada siklus II masih terdapat beberapa kelemahan yaitu : a. Dalam pembelajaran guru langsung menerangkan pada tema hari ini, guru tidak bertanya kegiatan yang telah anak lakukan pada hari sebelumnya (apersepsi); b. Pada saat kegiatan berlangsung, guru tidak melakukan penilaian. Pada siklus III kelemahan-kelemahan peneliti di siklus II diperbaiki, kemampuan melaksanakan kegiatan pembelajaran mengalami peningkatan sebesar 1,06 dengan persentase $8,82 \%$, menjadi 9,675 dengan persentase $80,62 \%$. Nampak bahwa peningkatan kemampuan melaksanakan pembelajaran dengan gain (rentang) tertinggi adalah siklus I ke siklus II mengalami peningkatan sebesar 1,065 dengan persentase $8,89 \%$.

Sedangkan dalam kemampuan guru dalam penggunaan media kartu kata bergambar pada siklus I sebesar 34 dengan persentase 56,67\%. Terdapat banyak kekurangan dan masih perlu diperbaiki pada siklus II. Pada siklus II kelemahankelemahan guru dalam menggunakan kartu kata bergambar diperbaiki dan mengalami peningkatan sebesar 11 dengan persentase 18,33\% menjadi 45 dengan persentase $75 \%$. Pada siklus II terdapat beberapa kelemahan diantaranya : Guru kurang melibatkan anak dalam menyebutkan gambar pada media kartu kata bergambar.Pada siklus III kelemahan-kelemahan tersebut diperbaiki dan mengalami peningkatan sebesar 9 dengan persentase $15 \%$ menjadi $90 \%$. Nampak bahwa peningkatan kemampuan menggunakan media kartu kata bergambar dengan gain (rentang) tertinggi adalah siklus I ke siklus II mengalami peningkatan sebesar 11 dengan persentase $18,33 \%$.

3. Penguasaan Kosakata Bahasa Sunda Anak Usia Dini

Penguasaan kosakata bahasa Sunda anak usia dini dari kondisi awal sampai siklus III mengalami peningkatan. Pada aspek mampu menyebutkan nama benda/gambar yang diperlihatkan guru pada indikator kata benda (kosakata umum), Kriteria BB (Belum Berkembang) pada kondisi awal sebesar 10\% (1 anak), sedangkan pada siklus I sampai III tidak ada satupun kriteria BB (Belum Berkembang). Kriteria MB (Mulai Berkembang) pada kondisi awal sebesar $40 \%$ (4 anak), siklus I sebesar 30\% (3 anak), siklus II dan siklus III tidak ada satupun kriteria MB (Mulai Berkembang). Kriteria BSH (Berkembang Sesuai Harapan) pada kondisi awal sebesar 50\% (5 anak), siklus I sebesar 50\% (5 anak), siklus II sebesar $80 \%$ (8 orang anak), dan siklus III tidak satupun dalam kriteria BSH (Berkembang Sesuai Harapan). Kriteria BSB (Berkembang Sesuai Harapan) pada kondisi awal tidak satupun mencapai kriteria tersebut, sedangkan pada siklus I dan siklus 2 sebesar 20\% (2 anak), dan siklus III sebesar 100\% (10 anak). Dari data tersebut penguasaan kosakata bahasa Sunda dalam aspek mampu menyebutkan nama benda/gambar yang diperlihatkan guru pada indikator kata benda (kosakata umum) 
mengalami peningkatan. Hal tersebut terlihat dari perubahan kriteria, dari BB (Belum Berkembang) menjadi MB (Mulai Berkembang), dari MB (Mulai Berkembang) menjadi BSH (Berkembang Sesuai Harapan), dan dari BSH(Berkembang Sesuai Harapan) menjadi BSB (Berkembang Sesuai Harapan), sehingga pada siklus III semua anak sudah mencapai kriteria BSB (Berkembang Sesuai Harapan).

Pada aspek mampu menyebutkan nama benda/gambar yang diperlihatkan guru pada indikator kata benda (kosakata umum), Kriteria BB (Belum Berkembang) pada kondisi awal sebesar 20\% (2 anak), sedangkan pada siklus I sampai III tidak ada satupun kriteria BB (Belum Berkembang). Kriteria MB (Mulai Berkembang) pada kondisi awal sebesar 40\% (4 anak), siklus I sebesar 30\% (3 anak), siklus II sebesar 10\% (1 anak) dan siklus III tidak ada satupun kriteria MB (Mulai Berkembang). Kriteria BSH (Berkembang Sesuai Harapan) pada kondisi awal sebesar 40\% (4 anak), siklus I sebesar 70\% (7 anak), siklus II sebesar 70\% (7 orang anak), dan siklus III sebesar 30\% (3 anak). Kriteria BSB (Berkembang Sesuai Harapan) pada kondisi awal dan siklus I tidak satupun mencapai kriteria tersebut, siklus 2 sebesar 20\% (2 anak), dan siklus III sebesar $70 \%$ (7 anak). Dari data tersebut penguasaan kosakata bahasa Sunda dalam aspek mampu menyebutkan nama benda/gambar yang diperlihatkan guru pada indikator kata benda (kosakata umum) mengalami peningkatan. Hal tersebut terlihat dari perubahan kriteria, dari BB (Belum Berkembang) menjadi MB (Mulai Berkembang), dari MB (Mulai Berkembang) menjadi BSH (Berkembang Sesuai Harapan), dan dari BSH (Berkembang Sesuai Harapan) menjadi BSB (Berkembang Sesuai Harapan), sehingga pada siklus III semua anak sudah mencapai kriteria BSH (Berkembang Sesuai Harapan) dan BSB (Berkembang Sesuai Harapan).

Pada aspek mampu menyebutkan kembali kata-kata yang baru dikenal indikator kosakata benda (kosakata umum), kriteria BB (Belum Berkembang) pada kondisi awal sebesar 30\% (3 anak), sedangkan pada siklus I sampai III tidak ada satupun kriteria BB (Belum Berkembang). Kriteria MB (Mulai Berkembang) pada kondisi awal sebesar 20\% (2 anak), siklus I sebesar 50\% (5 anak), siklus II dan siklus III tidak ada satupun kriteria MB (Mulai Berkembang). Kriteria BSH (Berkembang Sesuai Harapan) pada kondisi awal sebesar 50\% (5 anak), siklus I sebesar 50\% (5 anak), siklus II sebesar 60\% (6 orang anak), dan siklus III sebesar $80 \%$ (8 anak). Kriteria BSB (Berkembang Sesuai Harapan) pada kondisi awal tidak satupun mencapai kriteria tersebut, siklus I sebesar $20 \%$ (2 anak), siklus 2 sebesar 40\% (4 anak), dan siklus III sebesar 20\% (2 anak). Dari data tersebut penguasaan kosakata bahasa Sunda dalam aspek mampu menyebutkan nama benda/gambar yang diperlihatkan guru pada indikator kata benda (kosakata umum) mengalami peningkatan. Hal tersebut terlihat dari perubahan kriteria, dari BB (Belum Berkembang) menjadi MB (Mulai Berkembang), dari MB (Mulai Berkembang) menjadi BSH (Berkembang Sesuai Harapan) , dan dari BSH (Berkembang Sesuai Harapan) menjadi BSB (Berkembang Sesuai Harapan), sehingga pada siklus III semua anak sudah mencapai kriteria BSH (Berkembang Sesuai Harapan) dan BSB (Berkembang Sesuai Harapan).

Pada aspek mampu menyebutkan kembali kata-kata yang baru dikenal indikator kosakata warna (kosakata khusus), Kriteria BB (Belum Berkembang) pada kondisi awal sebesar 30\% (3 anak), sedangkan pada siklus I sampai III tidak ada satupun kriteria BB (Belum Berkembang). Kriteria MB (Mulai Berkembang) pada kondisi awal sebesar 20\% (2 anak), siklus I sebesar 50\% (5 anak), siklus II dan siklus III tidak ada satupun kriteria MB (Mulai Berkembang). Kriteria BSH (Berkembang Sesuai Harapan) pada kondisi awal sebesar 50\% (5 anak), siklus I sebesar 50\% (5 anak), 
siklus II sebesar $40 \%$ (4 orang anak), dan siklus III sebesar $80 \%$ (8 anak). Kriteria BSB (Berkembang Sesuai Harapan) pada kondisi awal tidak satupun mencapai kriteria tersebut, siklus I sebesar 20\% (2 anak), siklus 2 sebesar 60\% (6 anak), dan siklus III sebesar $20 \%$ (2 anak). Dari data tersebut penguasaan kosakata bahasa Sunda dalam aspek mampu menyebutkan nama benda/gambar yang diperlihatkan guru pada indikator kata benda (kosakata umum) mengalami peningkatan. Hal tersebut terlihat dari perubahan kriteria, dari BB (Belum Berkembang) menjadi MB (Mulai Berkembang), dari MB (Mulai Berkembang) menjadi BSH (Berkembang Sesuai Harapan) , dan dari BSH (Berkembang Sesuai Harapan) menjadi BSB (Berkembang Sesuai Harapan), sehingga pada siklus III semua anak sudah mencapai kriteria BSH (Berkembang Sesuai Harapan) dan BSB (Berkembang Sesuai Harapan).

\section{Simpulan}

Berdasarkan hasil penelitian dan temuan di lapangan tentang "Penggunaan Media Kartu Kata Bergambar untuk Meningkatkan Penguasaan Kosakata Bahasa Sunda Anak Usia Dini pada Kelompok B di TK PGRI Cibeureum", dapat diperoleh kesimpulan sebagai berikut :

1. Perencanaan pembelajaran melalui media kartu kata bergambar untuk meningkatkan kosakata bahasa Sunda anak usia dini pada kelompok B di TK PGRI Cibeureum, dengan memperhatikan petunjuk Penelitian Tindakan Kelas yang diberlakukan dan refleksi dari setiap siklus pembelajaran dapat meningkatkan penguasaan kosakata bahasa Sunda anak usia dini pada kelompok B di TK PGRI Cibeureum.

2. Proses pembelajaran dengan menggunakan media kartu kata bergambar untuk meningkatkan penguasaan kosakata bahasa Sunda anak usia dini ternyata dapat meningkatkan kemampuan guru dalam kegiatan belajar mengajar tentang kosakata bahasa Sunda anak usia dini pada kelompok B di TK PGRI Cibeureum.

3. Penguasaan kosakata bahasa Sunda anak usia dini pada kelompok B di TK PGRI Cibeureum melalui media kartu kata bergambar mengalami peningkatan.Hal tersebut ditunjukkan oleh kriteria keberhasilan yang telah dicapai oleh anak, sebanyak 60\% sudah mencapai BSB (Berkembang Sangat Baik).

\section{Saran}

Dalam rangka meningkatkan kualitas pembelajaran penguasaan kosakata bahasa Sunda anak usia dini, peneliti menyampaikan beberapa rekomendasi sebagai berikut.

1. Dalam melaksanakan pembelajaran penguasaan kosakata bahasa sunda anak usia dini, selain menggunakan kartu kata bergambar hendaknya guru memilih permainan yang beragam menggunakan media kartu kata bergambar, misalnya permainan mencari kartu, tebak kartu dan lain-lain.

2. Bagi peneliti selanjutnya yang tertarik dengan penelitian penguasaan kosakata bahasa Sunda anak usia dini sebaiknya mencoba kosakata yang lain atau dengan permainan yang lain yang lebih beragam.

\section{Daftar Pustaka}

Annisa, R. (2015). Meningkatkan Kosakata Bahasa Sunda dengan Model Pembelajaran Multisensori melalui Permainan Tradisional : Antologi UPI . Hlm.6.

Apriliani, Sindi. (2016). Penggunaan Strategi Membuat Gambar untuk Meningkatkan Kemampuan Pemecahan Masalah Siswa pada Materi Perbandingan. (Skripsi, Universitas Pendidikan Indonesia Kampus Tasikmalaya, 2016, tidak diterbitkan).

Arikunto, Suharsimi.(2013). Prosedur Penelitian : Suatu Pendekatan. Edisi Revisi 2010. Bandung : Rineka Cipta.

Arsyad, Azhar. (1997). Media Pembelajaran. Jakarta : PT Raja Grafindo Persada. 
Dhienie, Nurbiana dkk. (2007). Metode Pengembangan Bahasa. Jakarta. : Universitas Terbuka.

Dimyati, Johni. (2013). Metodologi Penelitian Pendidikan \& Aplikasinya pada Pendidikan Anak Usia Dini (PAUD). Jakarta : Kencana Prenada Media Grup.

Dinas Pendidikan Pemerintah Provinsi Jawa Barat. (2007). Standar Kompetensi dan Kompetensi Dasar Mata Pelajaran dan Sastra Bahasa Sunda. Bandung : Dinas Pendidikan Pemerintah Provinsi Jawa Barat.

Gelfgren, Veronica. (2012). Fun With Flashcard (150+ ideas for using flashcards in the classroom). Swedish : Learnmore Projects.

Hurlock, Elizabeth B. (1978). Perkembangan Anak Jilid I.(Child Development). Jakarta : Erlangga.

Latif, Mukhtar, dkk. (2013). Orientasi Baru Pendidikan Anak Usia Dini. Jakarta : Kencana Prenada Media Group.

Mansur. (2005). Pendidikan Usia Dini dalam Islam. Yogyakarta : Pustaka Pelajar.

Nurani Sujiono, Yuliani. (2013). Konsep Dasar Pendidikan Anak Usia Dini. Jakarta : PT Indeks.

Permendikbud Nomor 137 tahun 2014 tentang Standar Nasional Pendidikan Anak Usia Dini.

Sugiyono. (2012). Metode Penelitian Pendidikan Pendekatan Kuantitatif, Kualitatif dan $R \& D$. Bandung : Alfabeta.

Susilana, Rudi, dan Cepi. (2009). Media Pembelajaran. Bandung : $\mathrm{CV}$ WACANA PRIMA.

Tarigan, Hendri. (2011). Pengajaran Kosa Kata. Bandung : Angkasa.

Wardhani, IGAK, dan Kuswaya.(2009).Penelitian Tindakan kelas. Jakarta : Universitas Terbuka. 